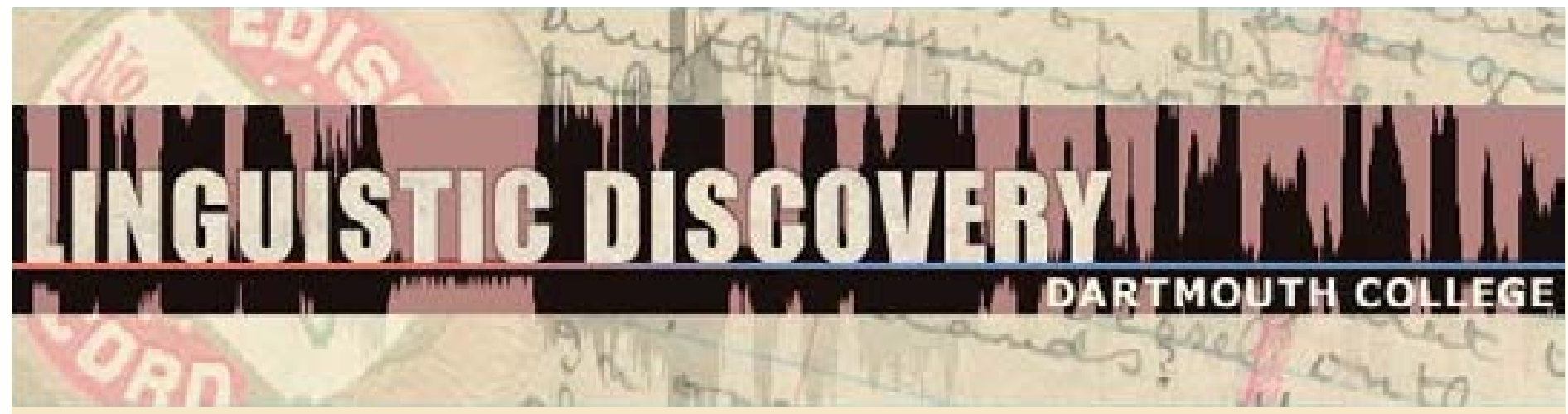

Volume 4 Issue 1 2006

\section{Training Speakers of Indigenous Languages of Latin America at a US University}

Tony Woodbury

Nora England

University of Texas

doi: 10.1349/PS1.1537-0852.A.301

url: http://journals.dartmouth.edu/cgi-bin/WebObjects/ Journals.woa/1/xmlpage/1/article/301 


\section{Training speakers of indigenous languages of Latin America at a US university \\ Tony Woodbury (acw@mail.utexas.edu) \\ Nora England (nengland@mail.utexas.edu) \\ University of Texas \\ Introduction}

This poster presents our experiences since 2001 with the University of Texas' Center for Indigenous Languages of Latin America (CILLA). 
The core idea of CILLA is to recruit into our Linguistics and Anthropology $\mathrm{Ph} . \mathrm{D}$. programs promising graduate students from indigenous communities in Latin America. The students focus on documentary and descriptive linguistics, which we take as the starting point for both scientific study and community language activism.

We feel that our work so far with ten indigenous students from Mexico, Guatemala, Panama, and Peru has had and will have a profound effect on the character of training of all Latin Americanist linguists at UT, whether indigenous or not; and on training in general linguistics and anthropology.

It has also led to research by students and faculty which, we argue, takes a highly integrative approach to the relationship between practical and scientific agendas about language in indigenous communities. We are pleased to be joined in this poster session by two sets of our students presenting their work: Christine Beier and Lev Michael, The Iquito language documentation project, and 
Emiliana Cruz and Hilaria Cruz, Chatino language activism through documentation and training in Cieneguilla \& San Juan Quiahije, Oaxaca.

We hope to encourage those in other universities contemplating such a program for themselves in a way that suits their own interests, needs, and world position.

The poster gives a short history of CILLA; a description of its organization and program operation; a discussion of research on indigenous languages of Latin America by students and faculty; and an assessment of the impacts of the program so far.

An earlier, written work on this theme appeared as Woodbury and England 2004. 
1. CILLA

THE CENTER FOR INDIGENOUS LANGUAGES OF LATIN AMERICA 


\section{CILLA's Origin}

- Spurred by a major UT initiative on Latin America, a multidisciplinary faculty group formed in 1998 to plan a Center for Indigenous Languages of Latin America (CILLA)

- The case we made to our provost and deans

$\circ$ Indigenous languages are an entryway to the study of indigenous communities and movements in Latin America

$\circ$ Latin America's endangered linguistic diversity is of scientific and humanistic interest

$\bigcirc$ Existing faculty and assets are strong in requisite areas

- Nora England was hired in Spring, 2001, as founding director of CILLA

- CILLA began operation in Fall, 2001 


\section{CILLA's Core Idea}

- England proposed that in the long run, the best way to do good research on indigenous languages of Latin America was to offer state of the art graduate training in language documentation and description to new generations of speakers

- The mission to train indigenous students also profoundly affects

- Training of non-indigenous Latin Americanists

- Training of students in linguistic theory

- Language advocates in speech communities

- Documentation and description--making records and compiling grammars and dictionaries - serve as foundations for different indigenous-language stakeholders, including: 
- Community language advocates with social, political, economic, aesthetic, and spiritual motivations for language investigation and preservation

$\circ$ Linguists (whether or not also community members) with scientific interests in linguistic diversity, universality, and prehistory

$\bigcirc \quad$ The university and wider public with humanistic interests in linguistic diversity 


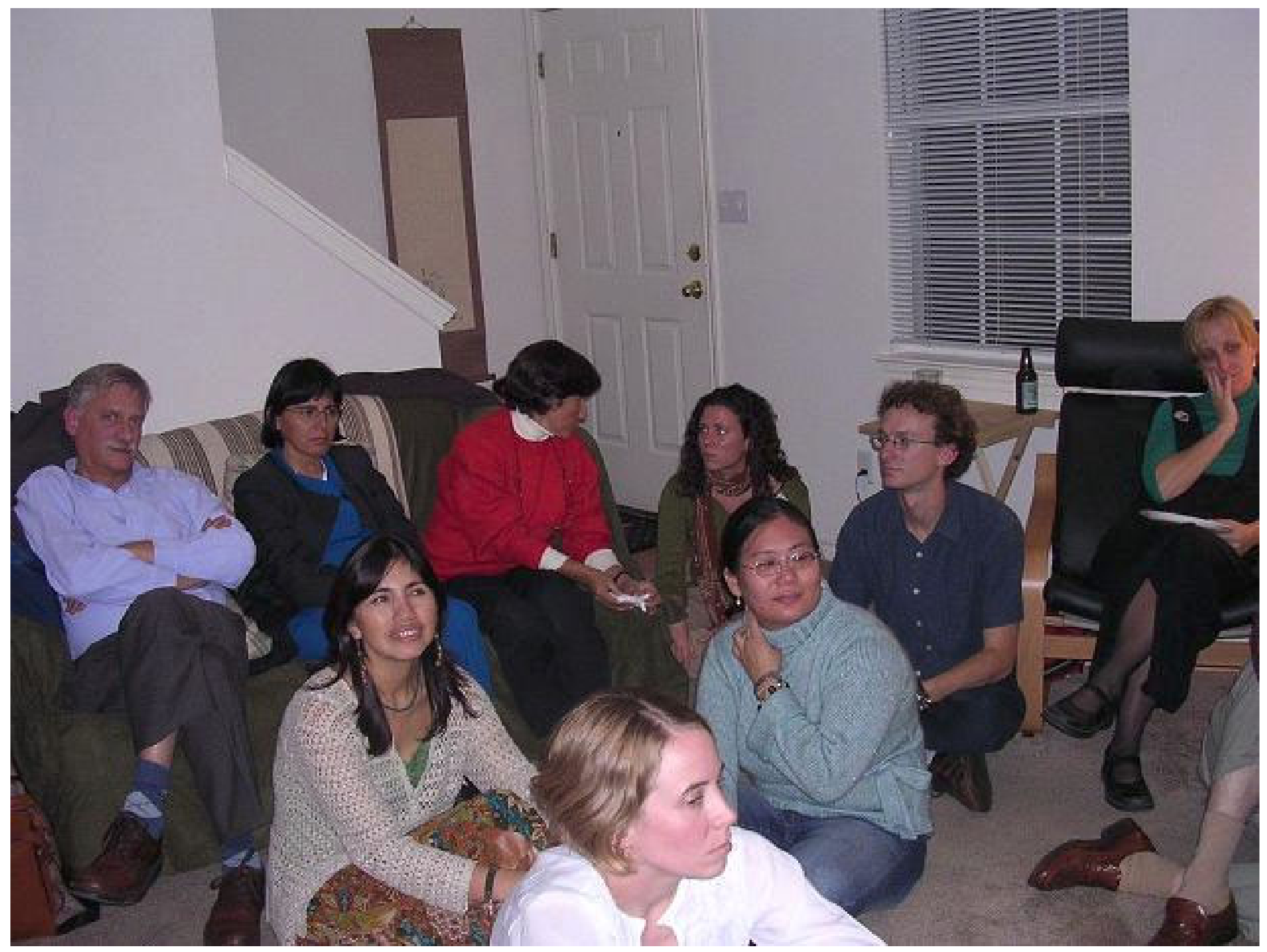

Amazonianists gather at the CILLA 2 Conference, Austin, October, 2005 


\section{CILLA's Set-Up}

- CILLA is an Organized Research Unit within UT's Teresa Lozano-Long Institute of Latin American Studies

- Director's (England's) faculty line and office are in Linguistics

- Indigenous students apply and enter as regular M.A. and Ph.D. students in Linguistics or Anthropology; study English if necessary

- CILLA initial operating budget includes funding for

- A year of English training for two students per year

○ Conferences involving indigenous and non-indigenous Latin American colleagues

- Visiting scholars from Latin America

○ But no research budget (research finds its own funding) 


\section{CILLA Faculty}

The entire Linguistics and Anthropology faculties teach CILLA students, but the following have special interests in Latin American indigenous languages

- Megan Crowhurst. Linguistics. Phonology; Zapotecan; Tupian languages of Bolivia.

- Nora England. Linguistics/Anthropology. Mayan languages; documentary/descriptive linguistics; language and identity.

- Pattie Epps. Linguistics. Documentary/descriptive linguistics, Hup, languages of Brazil, sociolinguistics, typology

- Joel Sherzer. Anthropology/Linguistics. Documentation, archiving, speech play, Kuna, Latin American areal features

- Tony Woodbury. Linguistics/Anthropology. Chatino, Yupik, documentary/descriptive linguistics, endangerment. 


\section{CILLA Activities}

- Conferences in Spanish, featuring indigenous and and nonindigenous colleagues from Latin America

- Biennial Conference on Indigenous Languages of Latin America (CILLA-1 in 2003 and CILLA-2 in 2005)

○ Yearly special topic conferences (Topics have included 'Linguistics at the Service of Indigenous Languages' and 'Fostering Indigenous Literatures of Latin America'

- Visiting faculty (Dr. Roberto Zavala Maldonado, CIESASSureste, 2003; others planned)

- Regular gatherings (4 or 5 times per semester since 2002; mostly in Spanish) 


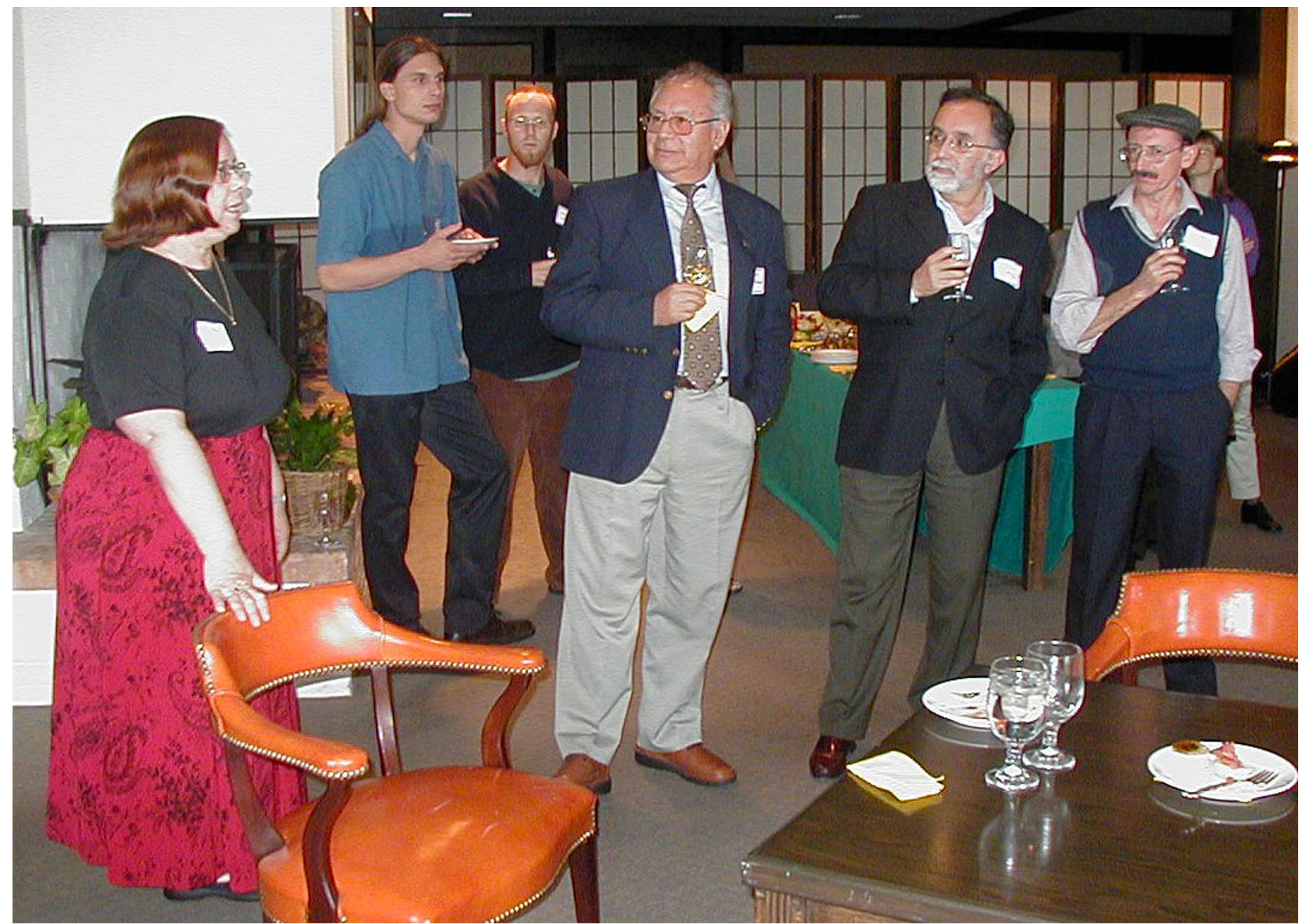

Foreground: Nora England, Rodolfo Cerrón Palomino, Luis Enrique López, Tulio Rojas Curieux at CILLA symposium "Linguistics at the Service of Indigenous Languages", April 4, 2002. 
2. PROGRAM OPERATION 


\section{Plan of Study}

- A year of English for those needing it

- Students seek M.A. and Ph.D. degrees in Linguistics or Anthropology

- Students follow the normal departmental program

○ Linguistics: Syntax I and II; Phonology I and II; Historical; Sociolinguistics; Semantics; and qualifying paper for advancement to Ph.D. candidacy

- Anthropology: Core courses in Social Anthropology and Linguistic Anthropology; Ph.D. candidacy exam 
- Students from both departments take electives in documentary/descriptive linguistics, e.g. Field Methods, Tools for Linguistic Description, The Structure of $\mathrm{X}$

- Linguists take advanced electives in general linguistics (phonetics/phonology, syntax/semantics, sociolinguistics); Anthropologists are encouraged to take the linguistics core courses

- At least one faculty member serves as a mentor who is familiar (or makes him/herself familiar!) with the linguistics of each student's native language in order to guide the student's progress 


\section{How CILLA fits in Linguistics and Anthropology}

- Indigenous students get the normal training in linguistics or anthropology while also pursuing the documentation, description, and preservation of their community language

- We encourage all students to work closely with different faculty and define themselves multiply (e.g., as documentary-descriptivist and specialist in language $\mathrm{X}$ and syntactician or linguistic anthropologist)

- We encourage all first-year students to "bond" as they take the core courses together (they seem to do it anyway!)

- We maintain a sense of community among all our Latin Americanists through CILLA activities, conducted in Spanish 


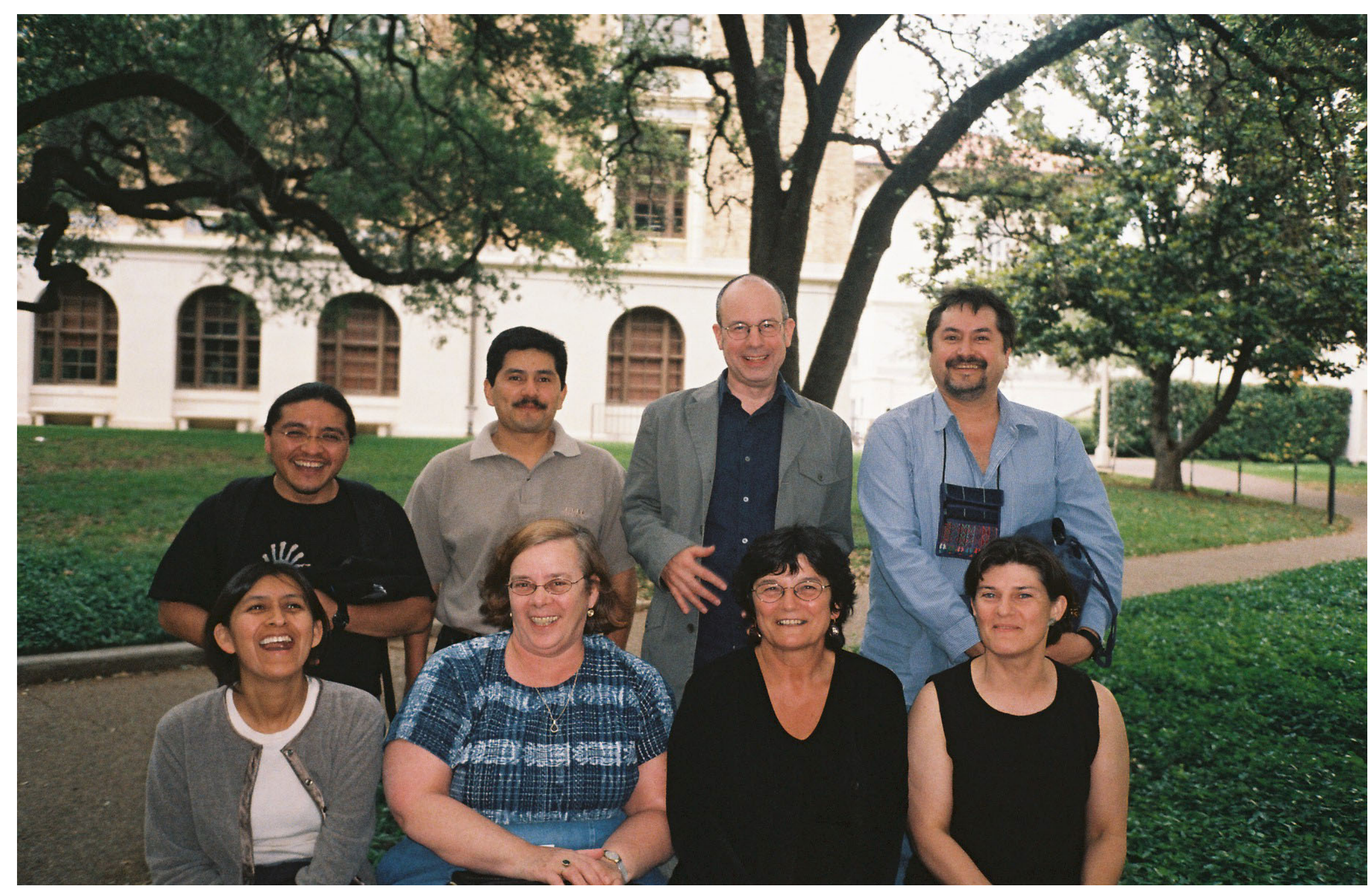

After the CILLA conference on Mesoamerican Languages, May, 2005. Front: Hilaria Cruz, Nora England, Colette Grinevald, Megan Crowhurst; Back: B'alam Mateo-Toledo, Juan Jésus Vázquez, Tony Woodbury, Roberto Zavala 


\section{Recruiting}

- We actively solicit applications to our Linguistics or Anthropology programs from indigenous language speakers with

○ B.A. or equivalent

- Aptitude for formal analysis

- Strong commitment to community language maintenance

- Recommendations from someone familiar with a program like ours (if possible)

- Applicants have come in response to our solicitation (in Spanish), or through encouragement by us, colleagues, or current students

- Backgrounds have varied: some had considerable prior exposure to linguistics, others didn't; some were already highly proficient in English, others weren't 


\begin{tabular}{|l|l|l|l|l|l|}
\hline Student & Country & Language & English & Entry & Department \\
\hline Ajb'ee Jiménez & Guatemala & Mam & - & 1999 & Anthropology \\
\hline B'alam Mateo-Toledo & Guatemala & Q'anjob'al & - & 2001 & Linguistics \\
\hline Emiliana Cruz Cruz & Mexico & Chatino & - & 2002 & Anthropology \\
\hline Tomas Cruz Cruz & Mexico & Chatino (H) & - & 2003 & L.A. Studies \\
\hline Hilaria Cruz de Abeles & Mexico & Chatino & - & 2004 & Linguistics \\
\hline Juan-Jesus Vázquez & Mexico & Chol & $2002-3$ & 2004 & Linguistics \\
\hline Wikaliler Smith & Panama & Kuna (H) & - & 2004 & Linguistics \\
\hline Felix Julca & Peru & Quechua & $2002-3$ & 2005 & Linguistics \\
\hline Amador Teodocio & Mexico & Zapotec & 2006 & 2006 & Linguistics \\
\hline Ausencia Lopez Cruz & Mexico & Zapotec & $2003-4$ & - & - \\
\hline Vidal Carbajal Solís & Peru & Quechua & $2003-4$ & - & - \\
\hline
\end{tabular}

Table: Current and recent graduate students from Latin American indigenous communities 


\section{Student Funding}

- Background. We have relatively large graduate programs and relatively little graduate support (But tuition is low and many students find TA-ships in other departments)

- UT was generous in providing initial support for indigenous students, with the expectation that outside funding would come along...but our early efforts were not too successful

- In 2004, The Ford Foundation's International Fellowship Program (http:fordifp.net/) proposed to fund indigenous students from five Latin American countries at UT, based on CILLA's experience and on their mission to work with "candidates from social groups...that lack systematic access to higher education" They now fund three of our students

- Two indigenous students (a US citizen and a US resident) received NSF graduate fellowships 
- One indigenous student is funded by Fulbright

- Several have received departmental funding in Linguistics and in Anthropology, or worked as GRAs for the Archive of Indigenous Languages of the Americas 
3. RESEARCH 


\section{Fostering Research}

- Premise Training indigenous students profoundly influences the type and quality of documentary linguistic research by graduate students and faculty (whether or not they are working in their own communities)

- Emergent characteristics of the research

- Collaborative (among student and faculty researchers and community members)

$\circ$ A mix of documentary, pedagogical, descriptive, and sociolinguistic projects

- Documentation and community work are springboards (not adjuncts) to scientific research, which develops alongside proximate, real-world goals 


\section{Current research efforts}

- The Iquito Language Documentation Project. A massive, teambased collaborative language revival effort centered around documentation and description, funded by the Hans Rausing Endangered Language Documentation Program, University of London.

- The Chatino Language Documentation Project. Community activism via literacy teaching and resource production for language awareness

- Mayan Languages Documentation Project. England and MateoToledo at UT, in collaboration with an indigenous academy, Oxlajuuj Keej Maya' Ajtz'iib' (OKMA) in Antigua, Guatemala; funded by NSF (Mateo-Toledo) and ELDP 
- Individual student field documentation projects. Generally at the doctoral level, funded by NSF, Fulbright, or ELDP. See list of student interests. 


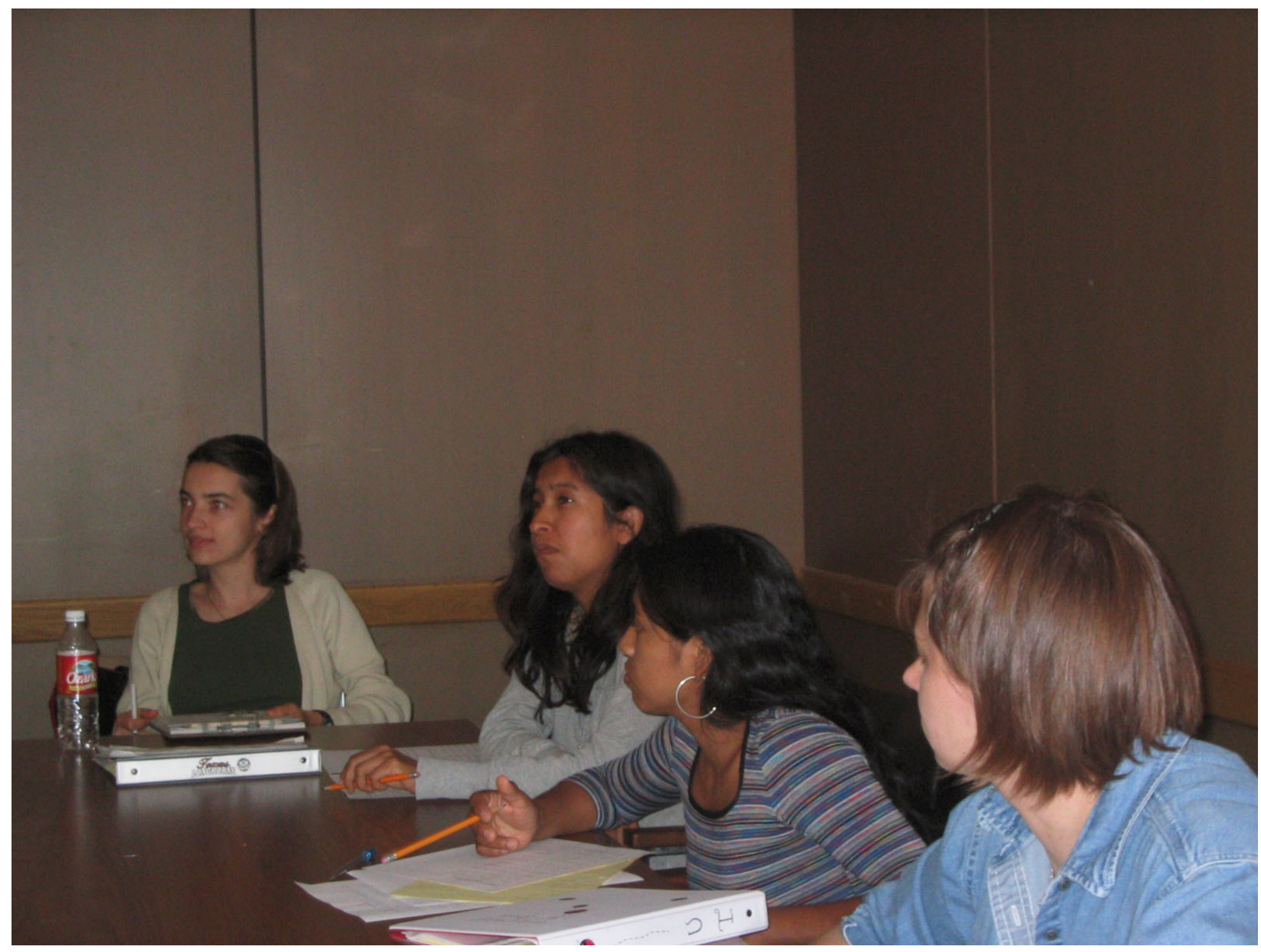

Structure of Chatino class, community preceptor training workshop, Austin, April, 2005; Alexandra Teodorescu, Yolanda Cruz, Gelacia Cruz, Alexis Palmer 


\section{Student research interests}

Cynthia Anderson. Linguistics, entering class of 2003. Interests: Nahuatl documentation and sociolinguistics; Iquito syntax.

Christine Beier. Anthropology, entering class of 1999. Interests: Nanti discourse and culture, Iquito documentation.

William Blunk. Linguistics, entering class of 2004. Interests: Yucatec Maya, verbal art and language in culture.

Lynda de Jong Boudreault. Linguistics, entering class of 2001. Interests: Iquito, Soteapan, descriptive and documentary linguistics, language teaching materials.

Michal Brody. Linguistics, Ph.D., 2004. Interests: Yucatec Maya writing and literacy.

Laura Cervantes. Anthropology, Ph.D., 2003. Interests: Bribri language, poetics, ritual, and music.

Emiliana Cruz. Anthropology, entering class of 2002. Interests: Chatino (her native language) documentation and description; community language activism.

Hilaria Cruz. Linguistics, entering class of 2004. Interests: Chatino (her native language), documentation and description; community language activism. 
Tomas Cruz. Latin American Studies, entering class of 2003. Interests: Chatino (his heritage language), identity and decision-making.

Simeon Floyd. Anthropology, entering class of 2002. Interests: Quichua, Amazonian languages, multilingualism.

Gabriela Garcia. Linguistics, entering class of 2005. Interests: Tepehuan (UtoAztecan), grammatical description

Maria Garcia. Anthropology, entering class of 2003. Interests: Ixil literacy and oral history.

Taryne Hallett. Linguistics, entering class of 2003. Interests: Iquito, linguistics of Costa Rica, sociolinguistics

Molly Harnisch. Linguistics, entering class of 2004. Interests: Iquito, pedagogy, discourse.

Kerry Hull. Anthrology, Ph.D., 2003. Interests: Ch'orti' poetics.

Ajb'ee Jiménez. Anthropology, entering class of 1999 Interests: Mam (his native language), community, identity, and language politics.

Felix Julca. Linguistics, entering class of 2005. Interests: Quechua (his native language), language and educational policy.

Susan Kung. Linguistics, entering class of 1996. Interests: Tepehua, descriptive linguistics. 


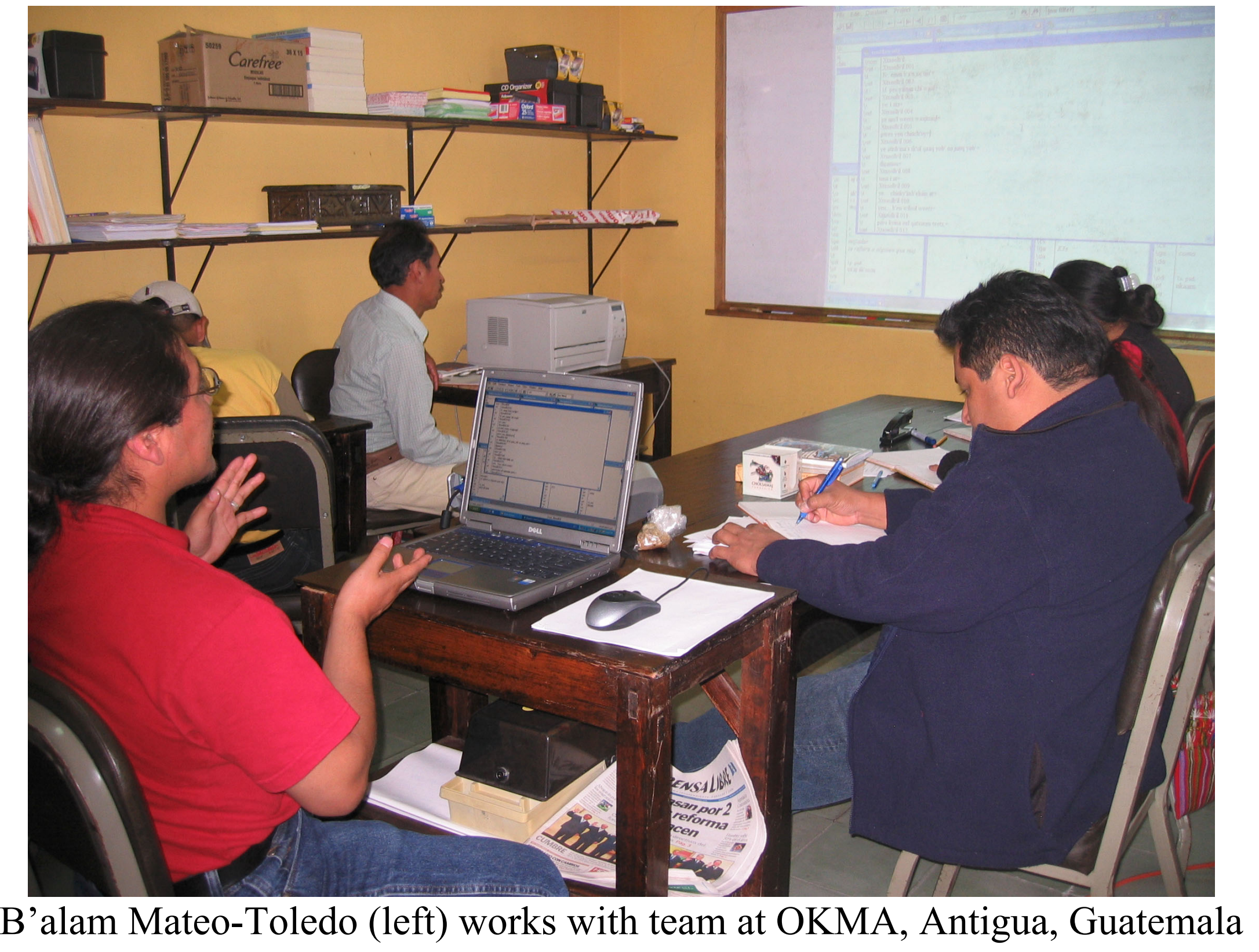


I-Wen Lai. Linguistics, entering class of 2002. Interests: Iquito, grammatical description.

Ausencia López Cruz. Intensive English, 2003. Interests: Zapotec (her native language), grammar.

B'alam Mateo-Toledo. Linguistics, entering class of 2001. Interests: Q'anjob'al (his native language), other Mayan languages, particularly Awakateko and Mocho', syntax, syntax/semantics/pragmatics interface, language description and documentation.

Lev Michael. Anthropology, entering class of 1999. Interests: Nanti, Iquito, descriptive and documentary linguistics, discourse, phonology, grammar.

Vivian Newdick. Anthropology, entering class of 2001. Interests: Political discourse in Chiapas indigenous communities.

Aaron Ponce. Linguistics, entering class of 2004. Interests: Descriptive and documentary linguistics.

Kayla Price. Anthropology, entering class of 2003. Interests: Kuna language planning, orthography, discourse.

Brianna Rauschuber. Linguistics, entering class of 2004. Interests: Descriptive and documentary linguistics, phonology; Iquito. 
Wikaliler Daniel Smith. Linguistics, entering class of 2004. Interests: Kuna (his heritage language), documentation and description.

Vidal Carbajal Solís. Intensive English, 2004. Interests: Quechua (his native language), language policy.

Heather Teague. Anthropology, entering class of 2004. Interests: Q'eqchi', indigenous politics.

Juan Jesús Vázquez. Linguistics, entering class of 2004. Interests: Ch'ol (his native language), grammar.

Stephanie Villard. Linguistics, entering class of 2005. Interests: Chatino, languages of Oaxaca, grammar. 
4. IMPACTS OF TRAINING 


\section{Academic and Institutional Impacts}

Training indigenous students in language documentation and description

- Introduces crucial but usually-absent native speaker perspectives to Latin American languages at all levels, especially syntax, semantics, lexicon, discourse, and ethnography of speaking

- Asserts and helps meet a responsibility to communities whose languages we study (It's not enough just to make your overworked grad students "give back" to the community in their spare moments)

- Invites us to take indigenous students' (and their communities') linguistic agendas into account in our graduate teaching and research, for example 
- It helps focus linguistics on linguistic diversity alongside linguistic universality

- It opens data- and document production, use, management, and archiving as methodological problems

- It brings the theoretical/descriptive enterprise into direct dialog with community language advocacy (none of these are antithetical)

- It promotes productive interaction and exchange between students who are speakers of indigenous languages and those who are not, but who wish to work on them (it is very much a two-way street)

- We hope our experiences will encourage those in other universities contemplating such a program for themselves in a way that suits their own interests, needs, and world position 


\section{Community Impacts}

- Our students have shown a strong commitment to return to their communities; we expect they will take leadership positions in both technical linguistic and language policy matters

- We encourage a strongly collaborative approach in all projects, whether or not the linguists involved are community members

- We involve indigenous linguistic enterprises in projects and actively build links to them and to local scholars

- Some examples so far

O B'alam Mateo-Toledo is coordinating a team of OKMA researchers in project on documentation of Mayan languages in Guatemala, and involving them in his own research, and has also worked with people in his own community 
- Chatino project members Emiliana and Hilaria Cruz have found and addressed high levels of local interest in literacy and language study both in their own community and other Chatino communities, teaching classes and training preceptors both in Oaxaca and in Austin

- The Iquito project signed a multi-year contract with the Iquito community which has led to the training of local field workers and teachers, to extensive teaching materials, and to regular adult and youth classes in Iquito 


\section{ACKNOWLEDGMENTS}

Many thanks to all our UT students and colleagues - including those mentioned-who have commented on and contributed to the content of what we describe. We also wish to express our enormous gratitude to members of the UT administration who have continued to support and encourage us in this enterprise, especially Sheldon Ekland-Olson, UT's Provost; and Richard W. Lariviere, the Dean of the College of Liberal Arts.

Contact information: England nengland@mail.utexas.edu; Woodbury acw@mail.utexas.edu 


\section{REFERENCE}

Woodbury, Anthony C. and Nora England. 2004. Training speakers of indigenous languages of Latin America at a US University. Proceedings of the 2004 Hans Rausing Endangered Language Program Workshop "Training and Capacity Building for Endangered Languages Communities." Hans Rausing Endangered Language Programme, School of Oriental and African Studies, University of London. 